http://dx.doi.org/10.11646/phytotaxa.81.2.1

\title{
Dorstenia christenhuszii (Moraceae), a new species from the Taita Hills, Kenya
}

\author{
MARK W. CHASE ${ }^{1}$, KOEN W. THIJS ${ }^{2}$, PERIS KAMAU ${ }^{3} \&$ MICHAEL F. FAY ${ }^{1}$ \\ ${ }^{1}$ Jodrell Laboratory, Royal Botanic Gardens, Kew, Richmond, UK; email: m.chase@ kew.org \\ ${ }^{2}$ Division Forest, Nature and Landscape, University of Leuven, Leuven, Belgium \\ ${ }^{3}$ Botany Department, National Museums of Kenya, Nairobi, Kenya
}

\begin{abstract}
At the Mbololo locality of the endemic African violet (Streptocarpus teitensis, Gesneriaceae) in the Taita Hills, Kenya, a new species of Dorstenia (Moraceae) was discovered. It is described here and illustrated with photographs.
\end{abstract}

\section{Introduction}

The Taita Hills in southeastern Kenya belong to the chain of Eastern Arc Mountains that rise from the surrounding plains (of ca. 600-700 m elevation) to a series of peaks and ridges, with the highest point being Vuria $(2208 \mathrm{~m})$. The soils are deep and low in nutrients; they have a low $\mathrm{pH}$ and poor water-holding capacity. The Taita Hills are under the influence of the intertropical convergence zone that brings heavy rains twice yearly (April and November), but more important to the peaks are year-round rain-bearing clouds blown in from the Indian Ocean. At elevations above $1500 \mathrm{~m}$, the natural vegetation is characterised as secondary moist to intermediate forest, but the majority of the land is now used for agriculture or forestry; native forest patches are small and remain only on a few hilltops (Aerts et al. 2011, Beentje 1988).

The Eastern Arc Mountains, classified as one of the world's 25 most important biodiversity hotspots (Myers et al. 2000), extend from Kenya into Tanzania. There are many species shared by Taita with the Usambara Mountains, which lie just across the border in Tanzania. The once continuous forests were interrupted due to development of a drier climate in the lowlands, and this isolation has resulted in recent radiations of endemic taxa. Most notable are the narrow endemics like Meineckia ovata (E.A.Bruce) Jean F.Brunel (syn.: Zimmermannia ovata E.A.Bruce; Phyllanthaceae), which is restricted to a small patch in northern Ngangao, and an endemic African violet, Streptocarpus teitensis (B.L.Burtt) Christenhusz (2012: 8; syn.: Saintpaulia teitensis B.L.Burtt; Gesneriaceae), which is restricted to wet rocks in eastern Mbololo. In addition, Memecylon teitense Wickens (Melastomataceae) and the native coffee, Coffea fadenii Bridson (Rubiaceae), occur in both Ngangao and Mbololo (and also in the Pare Mountains, Tanzania), but are only frequent in Mbololo. The forest tree community of Mbololo differs significantly in composition from other Taita Hills forest fragments. Typical indicator tree species for this fragment are Chrysophyllum gorungosanum Engl., Coffea fadenii, Cynometra sp., Heinsenia diervilleoides K.Schum., Sorindeia madagascariensis DC. and Strychnos mitis S.Moore.

Unfortunately, these forests have suffered heavy loss caused by ever increasing human population, resulting in a $98 \%$ decrease of the indigenous forest cover. The remaining forest patches are small, often less than 5 ha, and on hilltops. Therefore, saving these areas from further human interference should receive priority.

In February 2012, an expedition to the Taita Hills, Kenya, was carried out to study the fern diversity and extent and current status of the natural forests and to collect seeds and cuttings of endangered native plant species. Mbololo, Ngangao, Vuria and Yale were visited. On the eastern slopes of Mbololo around $1600 \mathrm{~m}$ 
elevation, we found a species of Dorstenia section Kosaria (Forsskål 1775: 164) Fischer \& Meyer (1846: 67), which is characterised by succulent (but not caudiciform), mostly branched stems, entire, deeply lobed laminas, short petioles, subulate stipules and inflorescences with filiform appendages mostly in two rows usually of different lengths. Pantropical Dorstenia comprises 105 species globally with ca. 58 species in Africa and is the second largest genus in Moraceae after Ficus. We describe this species from Mbololo as new.

\section{Taxonomy}

\section{Dorstenia christenhuszii M.W.Chase \& M.F.Fay, sp. nov. (Fig. 1)}

A species somewhat resembling the Tanzanian Dorstenia tenuiradiata Mildbraed (1934: 1065), but differing in its glabrous stems (vs. puberulous) and inflorescence margins with all appendices filiform (vs. the inner ones triangular-linear); inflorescences usually tinged purple.

Type:-KENYA. K7: Taita-Taveta District, Mbololo Hill, Mraru Ridge, primary forest along a stream with large boulders, 03 $19.916^{\prime}$ S, $038^{\circ} 27.078^{\prime}$ E, 1630 m, 22 February 2012, Christenhusz 6664, with P. Kamau, M. Mbale, J. Kyaa \& M.W. Chase (holotype K!, isotypes EA!, H!).

Fleshy herb to $80 \mathrm{~cm}$. Stems succulent, ascending, rooting at the base, unbranched or sparsely branched, up to $1 \mathrm{~cm}$ thick at base, glabrous. Leaves spirally arranged, subsessile; petiole short, $0.5-3.0 \mathrm{~cm}$, the blade attenuate to the $1 \mathrm{~mm}$ wide petiole wing; blade elliptic to obovate, $8.0-20.0 \times 2.5-6.0 \mathrm{~cm}$, bases attenuatecuneate, margins coarsely lobate-dentate in the upper half, usually with only one to a few lobes on each side, apices obtuse to acuminate; glabrous above, pubescent only on the midvein beneath, lateral veins in 5-7 pairs. Stipules subulate, caducous. Inflorescence, solitary, axillary; peduncle (1-)4-5 cm, densely pubescent. Receptacle discoid becoming semi-globose, resembling a shuttlecock, flowering face circular, ca $1-2 \mathrm{~cm}$. in diameter, margin up to $1.2 \mathrm{~mm}$ wide, appendages in two rows, the inner ones somewhat shorter than the outer ones, but all filiform in shape, up to $6 \mathrm{~cm}$ long, (usually) tinged purple. Staminate flowers spaced, perianth lobes 3; stamens 3, anthers two, white. Pistillate flowers spaced, numerous, with one green style. Pollinated by flies.

Other material examined:-KENYA. K7: Taita-Taveta District, Mbololo Forest, $3^{\circ} 19^{\prime} \mathrm{S}, 38^{\circ} 27^{\prime} \mathrm{E}$, forest on steep slopes, near forest stream, locally common, 1425-1850 m, 20 May 1985, Faden, Beentje, Ndegwa Ndiang'ui, Mutangah \& Nyakundi 765 (EA! US); Mbololo Forest, $3^{\circ} 19.58^{\prime} \mathrm{S}, 38^{\circ} 26.77^{\prime} \mathrm{E}, 1663 \mathrm{~m}, 27$ March 2010, Kamau 457 (EA!, H!); northwest of Mbololo forest, Kwambula water intake, Mrangi village, $3^{\circ} 32.538^{\prime} \mathrm{S}, 38^{\circ} 44.156^{\prime} \mathrm{E}, 1459 \mathrm{~m}$, a weak herb to $40 \mathrm{~cm}$ high growing in a forest stream with Tabernaemontana stapfiana, Newtonia buchananii, Phoenix reclinata, Strombosia scheffleri, Craibia zimmermannii and Macaranga sp., one population seen, 24 July 2009, Malombe \& Matheka 1233 (EA!); Mbololo forest, Kwambula water intake, $3^{\circ} 33.257^{\prime} \mathrm{S}, 38^{\circ} 44.669^{\prime} \mathrm{E}, 1558 \mathrm{~m}$, a herb to $50 \mathrm{~cm}$ high, growing in a deep forest valley with Macaranga capensis, Strombosia scheffleri, Podocarpus falcatus, Pteris pteridioides and Coffea fadenii, rare species, 27 June 2011, Matheka and Miyawa 841 (EA!); Mbololo forest, 0333S/ $38449 \mathrm{E}, 1700 \mathrm{~m}, 18$ August 2012, a herb to $80 \mathrm{~cm}$ high growing nearby a stream in a forest valley with Syzigium sclerophyllum, Newtonia buchananii, Strombosia scheffleri and Chrysophllum gorungosanum as dominant trees, Thijs, Steward, Keunen and Van de Peer (EA!)

Conservation:- -The IUCN conservation pre-assessment for Dorstenia christenhuszii is EN B1a (i, iii, v) $+2 \mathrm{a}(\mathrm{i}, \mathrm{iii}, \mathrm{v})$; C2a (i); D. Full assessment will follow after publication of the species. Area of occupancy is estimated to be less than $500 \mathrm{~km}^{2}$ in a forest facing fragmentation caused by increasing human populations. KT has also been in Chawia, Sagalla, Ndiwenyi, Kichuchenyi, Macha, Mwachora, Fururu and Ronge and only found $D$. brownii. The main current risk is the flammable, exotic plantations surrounding the indigenous forests. For instance, the Streptocarpus teitensis population was recently severely affected by fire.

Phenology:-All specimens examined were fertile, and this species flowers throughout the year, both in the wild and in cultivation. 

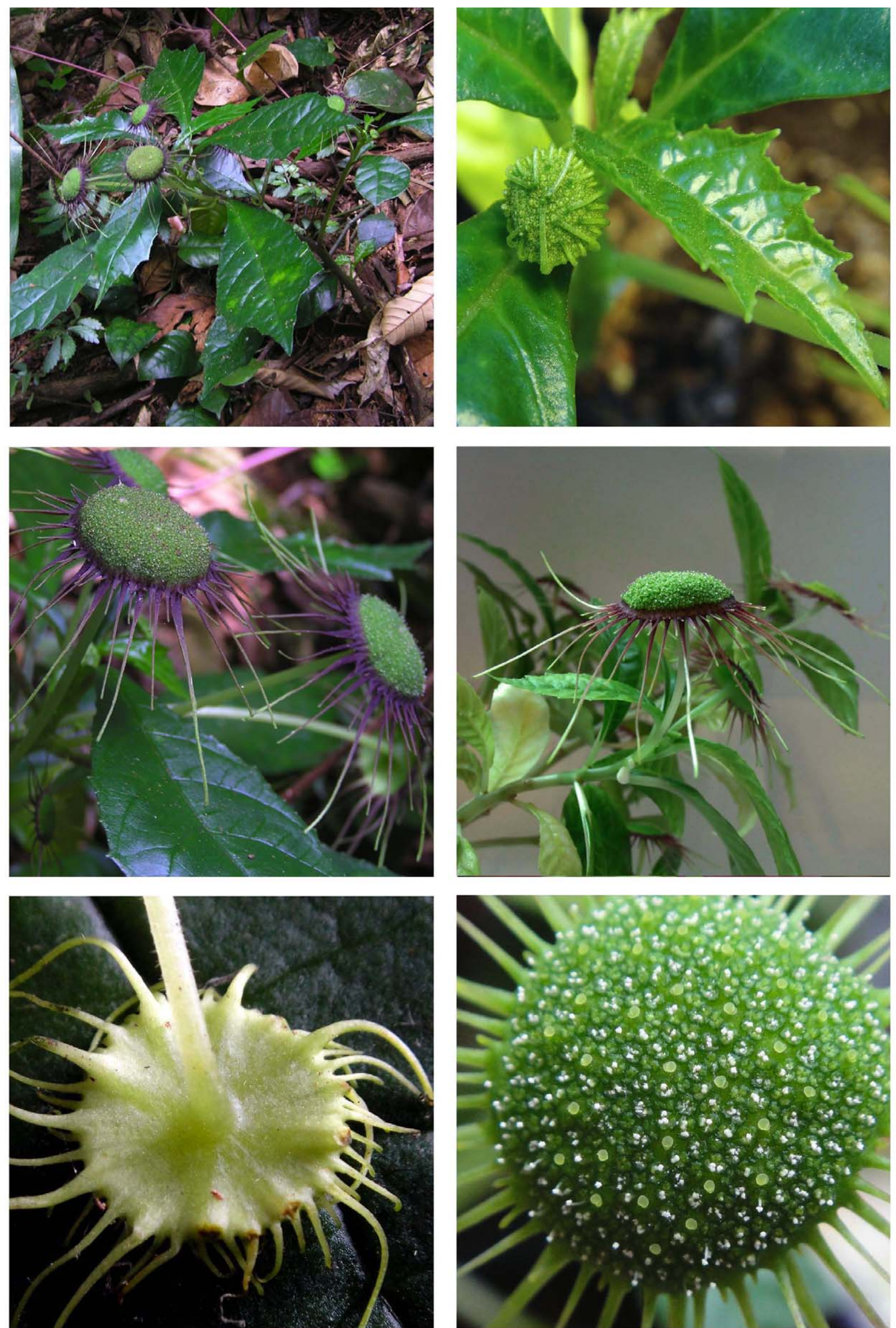

FIGURE 1. Photographs of Dorstenia christenhuszii. Top left, habit of adult plant (by K. Thijs); top right, immature inflorescence and new leaf (by M. Christenhusz); middle, inflorescences at anthesis (both by K. Thijs); bottom left, insertion of peduncle (by M. Christenhusz); bottom right, detail of inflorescence with open flowers (by M. Christenhusz). 
Distribution and ecology:-Known only from Mbololo forest, ca 1550-1700 m. Mbololo hill is southwest-northeast oriented and crossed by a less pronounced south-north oriented ridge that divides Mbololo forest in four quadrants. The species only occurs near small streams in the valleys of the two southern quadrants. These locations (K. Thijs, unpubl. data) are characterized by a high canopy cover (mean \pm SD: $77 \pm 8 \%, \mathrm{n}=5)$, shrub cover $(37 \pm 10 \%)$, litter cover $(87 \pm 7 \%)$ and leaf area index $\left(4.0 \pm 0.2 \mathrm{~m}^{2} / \mathrm{m}^{2}\right)$. The upper soil layer $(0-10 \mathrm{~cm})$ is characterized by soil acidity $\mathrm{pH}\left(\mathrm{H}_{2} \mathrm{O}\right)(4.7 \pm 0.7)$, soil conductivity $(502 \pm 265$ $\mu \mathrm{s} / \mathrm{cm})$, total phosphorus $(11.3 \pm 8.2 \mathrm{MgP} / \mathrm{kg})$, total nitrogen $(0.5 \pm 0.4 \%)$ and total soil organic matter $(3.1 \pm$ $0.6 \%)$. The most frequent tree species in the upper canopy layer (> 5m) are Strombosia scheffleri Engl., Tabernaemontana stapfiana Britten, Macaranga capensis (Baill.) Sim, Craibia zimmermannia (Harms) Dunn and Newtonia buchananii (Baker) Gilb. \& Bout. The understorey $(<5 \mathrm{~m})$ is dominated by Garcinia volkensii Engl., C. zimmermannia, Oxyanthus speciosus (K.Schum.) Bridson, Strychnos mitis S.Moore and Argomuellera macrophylla Pax. Tree regeneration is abundant for C. zimmermannia, Syzygium guineense F.White, N. buchananii, Xymalos monospora (Harv.) Warb. and Psychotria species.

Notes:-Even though this species is locally abundant, growing among boulders in creeks on steep slopes, it is only known from three collections. From the same area, D. brownii has also been recorded: Faden 70/ 552, EA!, K!; Kamau 457, EA!, MO!. However, this species is caudiciform at maturity or with an underground tuber and otherwise clearly morphologically distinct; the two are not easily confused.

Etymology:-The species epithet honours Dr Maarten J. M. Christenhusz (Founding Editor-in-Chief of Phytotaxa), who collected the type specimen and suspected that it was distinct from other East African Dorstenia species.

Cultivation:- The species grows easily from seed and cuttings, but it requires high humidity and shade to thrive. It is currently in cultivation at the Helsinki Botanical Gardens, the Royal Botanic Gardens, Kew, and the University of Leuven.

\section{Acknowledgments}

Mathias Mbale and Josephine Kyaa are thanked for assistance in the field and Patrick Muthoka for helping to obtain the necessary permits to collect plants in Kenya. Fieldwork was funded by the Finnish Museum of Natural History, Helsinki, Finland. Hassan Rankou advised on conservation assessment. Maarten Christenhusz provided specimen information.

\section{References}

Aerts, R., Thijs, K.W., Lehouck, V., Beentje, H., Bytebier, B., Matthysen, E., Gulinck, H., Lens, L. \& Muys, B. (2011) Woody plant communities of isolated Afromontane cloud forests in Taita Hills, Kenya. Plant Ecology 212: 639-649. http://dx.doi.org/10.1007/s11258-010-9853-3

Beentje, H.J. (ed.) (1988) An ecological and floristic study of the forests of the Taita Hills, Kenya. Utafiti 1-2: 23-66.

Berg, C.C. \& Hijman, M.E.E. (1989) Moraceae. In: Polhill, R.M. (ed.) Flora of tropical East Africa. Royal Botanic Gardens, Kew, Balkema, Rotterdam. 26 pp.

Berg, C.C. \& Hijman, M.E.E. (1999) The genus Dorstenia (Moraceae). Ilicifolia 2: 1-211.

Christenhusz, M.J.M. (2012) On African violets and Cape primroses-towards a monophyletic Streptocarpus (Gesneriaceae). Phytotaxa 46: 3-9.

Fischer, F.E.L. \& Meyer, C.A. (1846) Dorstenia. Index Seminum [St. Petersburg] 11: 65-67.

Forskål, P. (1775) Flora Aegyptiaco-Arabica. Möller, Copenhagen. 398 pp.

IUCN (2001). IUCN red list categories and criteria, version 3.1. Accessed online 24 August 2012: http:// www.iucnredlist.org/technical-documents/categories-and-criteria/2001-categories-criteria.

Mildbraed, J. (1934) Neue und seltene Arten. Notizblatt des Botanischen Gartens und Museums zu Berlin-Dahlem 11: 1058-1092. http://dx.doi.org/10.2307/3994612

Myers, N., Mittermeier, R.A., Mittermeier, C.G., da Fonseca, G.A.B. \& Kent, J. (2000) Biodiversity hotspots for conservation priorities. Nature 403: 853-858. http://dx.doi.org/10.1038/35002501 